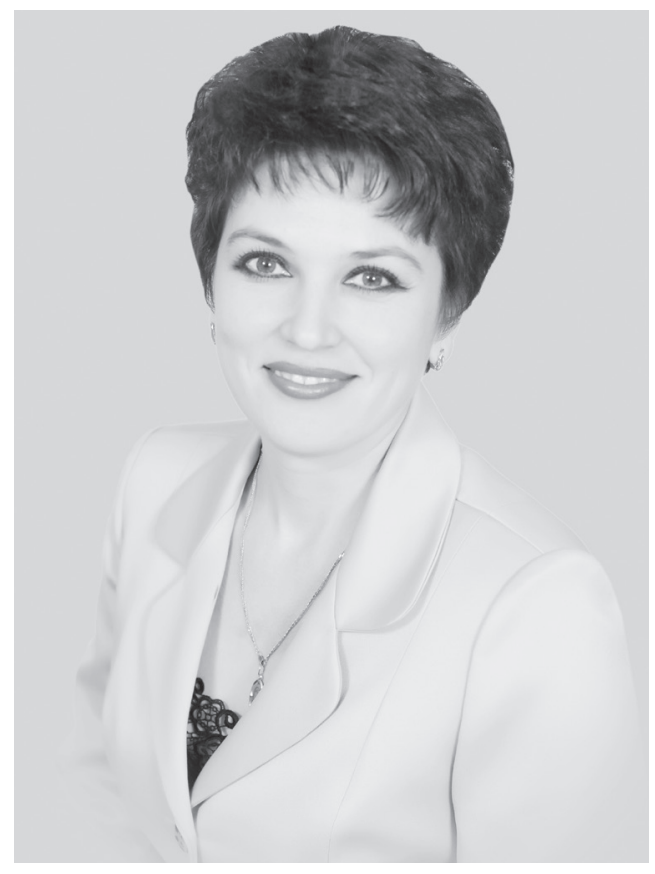

UDC: $\mathbf{3 1 6 . 4}$

DOI: https://doi.org/10.32689/2617-

2224-2019-18-3-238-249

Korchak Irina Mykolaivna,

graduate student, National Academy of

Public Administration under the President

of Ukraine, 02000, Kyiv, Str. Ezhena Potie, 20, tel.: +38067147 7859, +380674711907, e-mail:ikorchak@gmail.com

ORCID: 0000-0003-3737-5431

Корчак Ірина Миколаївна,

аспірант, Начіональна академія державного управління при Президентові України, 02000, м. Київ, вул. Ежена Потьє, 20, тел.: +380671477859, +380674711907, e-mail:ikorchak@gmail.com

ORCID: 0000-0003-3737-5431

Корчак Ирина Николаевна,

аспирант, Национальная академия государственного управления при Президенте Украины, 02000, г. Киев, ул. Эжена Потье, 20, тел.: +380671477859, +380674711907, e-mail: ikorchak@gmail.com

ORCID: 0000-0003-3737-5431

\title{
THE ESSENCE AND SIGNIFICANCE OF THE PUBLIC CONFLICT IN THE MODERN CONDITIONS OF DEVELOPMENT OF SOCIETY AND ITS CONNECTION WITH THE ARCHETYPES OF THE COLLECTIVE UNCONSCIOUS
}

Abstract. The article is devoted to the study of 'public conflict' in the system of public administration, the search for a more precise and scientifically-based version of the definition of the concept of 'public conflict'. In the period of global transformations and rapid pace of social development, conflicts arise that take on other forms that are not always related to social conflicts. By this time in the scientific literature mainly exploring and defining the conflict provided as social conflict, meets the definition of a political conflict, however, in terms of informatization and globalization a significant part of conflict situations moving to another is different from the above mentioned forms of conflict as 'public form'. In this article, the author not only introduces a new term 'public conflict', but rather revolutionary (as for conflict science as a science), justifies the need for a comprehensive and comprehensive study of this phenomenon and provides his own 
vision of the definition of 'Public Conflict'. Trying to explore the essence of 'public conflict' in the article focuses on its influence in the field of public administration, and simultaneously emphasizes that this is only one of the directions of research, the rest of the same directions need to be added to his study of all interested scientific community. Conditionally accepted in the article the term 'public conflict' often occurs in the field of public administration, especially its study of the sphere of public administration. The rational nature of modern conflicts leads to massive innovative activity, which results in dynamic changes in the institutional sphere of public life, including the institutions of the state.

The article analyses the events of recent years, during which there have been dramatic changes in the Ukrainian society, which were constantly accompanied by the intensification of conflict situations because of the contradictory nature of human life, in which each individual one way or another self-determines and selfasserts in the process of conflict-related interaction throughout life. The 'active principle of the ancestral' (according to K. Yung) is currently operating in Ukrainian society by rethinking and returning to the spiritual and moral values of the Ukrainian people, including hereditary ones. The outbreaks of conflict situations in Ukraine testify to the expansion of the social base, the polarization of society in the face of a sharp stratification. Therefore, research into this article of contemporary forms of conflict will provide comprehensive and universal prevention and resolution of conflicts in the future.

The $21^{\text {st }}$ century requires the personality of profound professional, informational knowledge, innovative skills, knowledge of new technologies, the manifestation of such virtues as spirituality and patriotism. In this dynamic of human progress towards sustainable development of a personality, the person always conflicts with his own 'Self' and the social 'We'.

Keywords: archetypes of the collective unconscious conflict, public policy, public conflict, social conflict.

\section{СУТЬ І ЗНАЧЕННЯ ПУБЛІЧНОГО КОНФЛІКТУ У СУЧАСНИХ УМОВАХ РОЗВИТКУ СУСПІЛЬСТВА ТА ЙОГО ЗВ'ЯЗОК 3 АРХЕТИПАМИ КОЛЕКТИВНОГО НЕСВІДОМОГО}

Анотація. Досліджено сучасну природу соціального конфлікту як об'єкта публічного управління, пошуку більш чіткого й науково обгрунтованого варіанта визначення самого поняття “публічний конфлікт”. У період глобальних перетворень і швидких темпів розвитку суспільства виникають конфлікти, які набувають нових форм, не завжди пов’язаних зі звичним уявленням щодо соціального конфлікту. До того ж в умовах інформатизації та глобалізації значна частина конфліктних ситуацій переходять у відмінну від зазначених форм конфліктів - “публічну”. Автор не просто вводить новий термін - “публічний конфлікт”, а досить революційно (як для конфліктологіі) обгрунтовує необхідність всебічного дослідження цього явища і надає своє бачення поняттю “публічний конфлікт”. Намагаючись дослідити сутність “публічного конфлікту”, акцентовано увагу на його поширенні у сфері публічного управ- 
ління і водночас наголошено, що це лише одна із суб’єктивних точок зору, яка вимагає належної об'єктивації і вивчення всім зацікавленим науковим співтовариством. Прийнятий умовно в статті термін "публічний конфлікт" найчастіше виникає у сфері публічного управління. Водночас його "раціональна сутність” так чи інакше стосується масової інноваційної активності людей, в результаті якої піддається динамічним перетворенням інституційна сфера суспільного життя, в тому числі інститути держави.

Проаналізовано події останніх років, упродовж яких відбулися радикальні якісні зміни в українському суспільстві. Вони супроводжувалися посиленням конфліктних ситуацій, які багато в чому відбуваються внаслідок суперечливої природи людини, її самовизначення і самоствердження в процесі конфліктологічної взаємодії. “Активний принцип спадкового” (за К. Юнгом) в даний час працює в українському суспільстві, змущуючи переосмислювати і повертатися до духовних і моральних цінностей українського народу. Спалахи конфліктних ситуацій в Україні свідчать про розширення соціальної бази поляризації суспільства на тлі його різкого розшарування. Тому дослідження сучасних форм конфліктів здатне забезпечити комплексне й універсальне запобігання і вирішення конфліктів у майбутньому.

XXI століття вимагає від особистості глибоких професійних, інформаційних знань, інноваційного таланту, знання нових технологій, прояву таких якостей, як духовність і патріотизм. У цій спрямованості до сталого розвитку суспільства особистість завжди вступає у конфлікт з власним "Я” і громадським "Ми".

Ключові слова: архетипи колективного несвідомого, конфлікт, публічна політика, публічний конфлікт, соціальний конфлікт.

\section{СУЩНОСТЬ И ЗНАЧЕНИЕ ПУБЛИЧНОГО КОНФЛИКТА В СОВРЕМЕННЫХ УСЛОВИЯХ РАЗВИТИЯ ОБЩЕСТВА И ЕГО СВЯЗЬ С АРХЕТИПАМИ КОЛЛЕКТИВНОГО БЕССОЗНАТЕЛЬНОГО}

Аннотация. Исследована современная природа социального конфликта как объекта публичного управления, осуществлялся поиск более четкого и научно-обоснованного варианта определения самого понятия “публичный конфликт”. В период глобальных преобразований и быстрых темпов развития общества возникают конфликты, которые приобретают новые формы, не всегда связанные с привычным представлением социального конфликта. К тому же в условиях информатизации и глобализации значительная часть конфликтных ситуаций переходят в другую - отличную от вышеупомянутых форм конфликтов - “публичную”. Автор не просто вводит новый термин - “публичный конфликт”, а достаточно революционно (как для конфликтологии) обосновывает необходимость всестороннего исследования этого явления и предоставляет свое видение понятия “публичный конфликт”. Пытаясь исследовать сущность ”публичного конфликта”, внимание акцентируется на его влиянии в сфере государственного управления и од- 
новременно подчеркивается, что это лишь одна из субъективных точек зрения, которая требует должной объективации и изучения всем заинтересованным научным сообществом. Принятый условно в статье термин “публичный конфликт" чаще всего возникает в сфере публичного управления. Вместе с тем его “рациональная сущность” так или иначе касается массовой инновационной активности, в результате которой подвергается динамическим преобразованиям институциональная сфера общественной жизни, в том числе институты государства.

Проанализированы события последних лет, в течение которых произошли радикальные качественные изменения в украинском обществе. Они сопровождались усилением конфликтных ситуаций, во многом происходящих вследствие противоречивой природы человека, его самоопределения и самоутверждения в процессе конфликтологического взаимодействия. “Активный принцип наследственного” (по К. Юнгу) в настоящее время работает в украинском обществе путем переосмысления и возвращения к духовным и нравственным ценностям украинского народа. Вспышки конфликтных ситуаций в Украине свидетельствуют о расширении социальной базы, поляризации общества на фоне его резкого расслоения. Поэтому исследование современных форм конфликтов способно обеспечить комплексное и универсальное предотвращение и разрешение конфликтов в будущем.

XXI век требует от личности глубоких профессиональных, информационных знаний, инновационного таланта, знания новых технологий, проявления таких качеств, как духовность и патриотизм. В этой устремленности к устойчивому развитию общества личность всегда вступает в конфликт с собственным “Я” и общественным “Мы”.

Ключевые слова: архетипы коллективного бессознательного, конфликт, публичная политика, публичный конфликт, социальный конфликт.

The problem is presented in general terms and its connection with important scientific and practical tasks. Economic globalization and the spread of information technology, the creation of virtual interest groups, new forms of identity politics, centred on religious beliefs, weak governments, backward economies, religious extremism, disproportionate growth in the number of young people. These factors will be combined, creating ideal conditions for internal conflicts in different regions [1, p. 5].
It is impossible to avoid conflicts and their consequences, and therefore the study of conflicts, changing the forms of conflict requires constant study and modelling, forecasting and prevention.

Analysis of recent publications on the issues and identification of previously unsettled parts of the general problem. An analysis of scientific studies and publications shows that many scientists from different countries and at different times engaged in the problem of identifying conflicts, their emergence and resolution and prevention. In 
the conditions of independent Ukraine, this issue was given attention by O. M. Bandurka, V. A. Druz, L. M. Herasina, M. I. Panov, V. Ya. Tatsii, Yu. M. Tadyk and M. I. Piren, etc.

But the changes that are taking place in the Ukrainian society are closely intertwined with the development of social processes in the world. In the conditions of the globalization of the world society, new challenges arise that cause conflicts in new manifestations and forms, especially in the context of informatization of society. One of the forms of conflict manifestation at the present time is a 'public conflict'. The specified form of conflict has not yet been thoroughly studied, but is already reflected in emergencies, and has become a factor in influencing political processes and decision-making processes in public and state administration.

The purpose of the article is through the historical analysis of the disclosure of the essence of the general concept of 'conflict' and understanding of the conflict in the current challenges of social change as to define and formulate one form of conflict, namely, as 'public'. This today forms the emergence of new social phenomena and the formation of new democratic values. Such a study of the conflict will enable us to meet the challenges of the information society in a globalized world and find ways to prevent and resolve these conflicts.

Presentation of the main research material with full objectivation of the received scientific results. The term 'conflict' comes from the Latin word 'conflictus'. It means collision. Conflicts are a natural phenomenon that is inherent in any society, especially modern society. Adequate understanding of the nature of the conflict and the professional use of modern methods of public administration depends to a large extent on the manageability, balance and non-conflict of the social system and its existence.

Conflict is a collision of opposite interests and views, tension and extreme sharpening of contradictions, which leads to active actions, complications, struggles, accompanied by complex collisions.

The history of human development from ancient times to the present day testifies that conflicts have always been and will be. The sciences of any profile (Philosophy, History, Culture, Political Science, and World Religions) operate the concepts of conflict through the concepts of good and evil, order and chaos. For example, historians look for identifying the causes of the development and decline of states and deep crises and long-term prosperity in the lives of individual peoples, because all these processes are problematic and conflicted [1, p. 23].

The nature of the conflicts was already conceived by ancient Greek philosophers: Anaximander (about 610-547 BC), Ancient philosopher Heraclitus (about 530-470 BC). In the Middle Ages, Thomas Aquinas (12251274), Erasmus Rotterdam (1469-1536) and Immanuel Kant (1724-1804), who considered the conflict as manifested as a factor in the war in society and in geopolitical processes.

Georg Hegel (1770-1831) wrote that the main cause of conflict is rooted in social polarization between the accumulated wealth, on the one hand, and the forced labour of the people on the other. 
Charles Darwin (1809-1902) proposed a theory of evolution, the main ideas of which are described in the work Origin of Species through Natural Selection, or Conservation of Favourable Breeds in the Struggle for Life. The development of wildlife is carried out in a constant struggle for survival, that is, a constant conflict; he considered [1, p. 24].

Great interest among conflictologists at the end of the $19^{\text {th }}$ and early $20^{\text {th }}$ centuries caused the sociological theory of conflict, which is reflected in the writings Karl Marx (1818-1883) as the theory of class struggle; G. Rattsenhofer (1842-1904) as the theory of conflict of social relations; and William Sumner (1840-1910) began the systematic study of the norms of social behaviour, intragroup and intergroup relations. German sociologist Georg Simmel (1858-1918) is considered the first to introduce the term 'sociology of conflict' into scientific use.

The theoretical reflections of G. Simmel were divided in the 20 years of the twentieth century. Sociologists at the Chicago School, whose prominent representatives were Robert Ezra Park (1864-1944), Ernest Watson Burgess (1886-1996) and Albion Woodbury Small (1854-1926). They considered the social process in the aspect of four interrelated types of interaction: competition, conflict, adaptation and assimilation [2].

The sociological significance of the conflict was determined by the American sociologist $A$. V. Small, who defined the conflict as a general conflict of interests, where individuals are a product of struggle for their own interests, and society is a consequence of a collision of social interests [1, p. 27].

In the first half of the $20^{\text {th }}$ century was dominated by the theory of social conflict and conflict as opposed to between minorities of management and managed by the majority is the eternal truth, which always different conflicts.

Starting from the middle of the $20^{\text {th }}$ century, there is an active development of scientific and practical understanding of conflicts.

Problems of conflict were devoted to the works of S. Freud, K. Jung, E. Bern and other authors.

Austrian psychologist Sigmund Freud (1856-1939) created one of the first concepts of conflictology as the theory of psychoanalysis. Carl Gustav Jung (1875-1961) founded a school of analytical psychology, put forward the concept of the existence of the collective unconscious, and suggested a typology of personality traits that to some extent explained the behaviour of the individual in conflict.

German sociologist Ralph Darendorf and other scholars generalized the theory of the 'conflict model of society', the dialectical theory of conflict, sought to identify and show the common causes for conflicts for all social systems, as well as identify ways to optimize the conflict process.

R. Darendorf singled out not only the negative sides of the conflict but also the positive ones. The conflict, in his opinion, may be a source of innovation and social change. Another American scientist M. Amstuti developed the idea of 'utility' and 'negativity' (harmfulness) of conflicts [1, P. 28].

K. Jung complements Freud's work by investigating the phenomenon of 
synchronicity and what he calls 'collective unconscious'. Scientist examines how synchrony phenomenon in which the outside world event in a meaningful way coincides with the mental state of man. This is a recurring experience, which is reflected in cases that do not obey the laws of time, space and causality. According to Young's definition, this 'working' in us is a collective unconscious, passed on from generation to generation and accumulates human experience. And the memory of the individual as an active principle of heredity consists of the memory of ancestors, 'invisible parents', whose power is born again with the child'. The latter, of course, does not know about these consequences. He only feels that something interferes with the free manifestation of his instincts; and he designs this internal barrier first on parents, and then on society [3, p. 16].

Today it's about the 'active principle of the ancestral' vividly displayed in the social development of the society and is reflected in social, economic, and political processes taking place in Ukraine and the development of information technology more these processes take place in a public plane.

The global changes that have taken place in Ukrainian society over the past 25 years have led to the unconsciously reproducing the once lost spiritual connection of the Ukrainian nation with 'the memory of ancestors'. This completely overturns the former Soviet imagination and the system of values in the current 'self-sufficient' (atomized) Ukrainian born by the Orange Revolution (2004) and tempered the Maidan of Dignity (2013-2014). Of course, that born in these events have brought new values and yet still find considerable inner conflict in all senior age cohorts society with the emergence of the phenomenon in the post-Soviet space, 'the private life' of a person goes into a public plane and is reflected above all in the social and political events in Ukraine.

The old collective and group values that have been destroyed in the process of social transformation generate personal conflicts that complement property, money and social stratification in society. In the end, the spiritual fall, the destruction of industrial ties, unemployment, etc. as all this has destroyed the former integrity of man as a person, but also does not contribute to the restoration of this integrity on the basis of new principles of self-sufficient identity and 'unique individual'.

The biggest problem for the working and most active part of the population was the fact that the working professional is not able to provide for himself and his family a decent standard of living. This erased the boundary between the classes among the classes of Ukrainian society, nominally fell into the middle class, which exists and develops, but it cannot materially provide itself where the paradox of the 'working beggar' originated, which, in addition to developing itself, has to spend its time on providing the material side of his/her life and way of life. This state of the individual generated a conflict between the needs of reality and individual capabilities.

E. Shostrom equates the situation of the conflict with the two party system of democracy: in each of us there is a two-party system of democracy in which one is a part of the power. The 
second one is a loyal opposition. But the opposition can assume not only control and criticism, but also a brutal struggle, i.e. conflict. [4, p. 73].

In the languages of such a conflict environment, in which the public is the last 27 years, a system of state power was created in Ukraine by representatives who seek self-realization through material enrichment at the expense of corruption schemes for theft of the state budget, namely, the human public domain. In such power representatives who are focused on rapid material enrichment, the boundaries of spiritual values, democratic values, which integrate into our society, have been eroded.

The country is torn by narrowly selfish interests, both the economic and political nature of various groups and individuals. The problem is that the formula that was determined at the start of the development of an independent state, which is still guided: first of all, reforms, and then the solution of social problems: it was not only false, but also deeply destructive and conflictive. In practice, it has come down to the wellknown: reforms due to social factors. Even the social achievements, which at one time were borrowed from the Western countries, were dismantled [5].

The crisis of spirituality has not been overcome, new values and ideals have not been established on the scene, the idea of national statehood under the influence of political struggle and social tension, which has become part of its supporters in separate regions, has lost some of its supporters and the Ukrainian nation remains unconsolidated. The situation in Ukraine, at the level of social consciousness, can be characterized rather by the notion of 'civil opposition' rather than 'concord' and 'understanding'.

At the same time, in today's world, a strong tendency is to focus on common human interests and the movement for civil rights of the individual. The centre of public debate is the issue of relations between state and civil institutions, transparency of power, environmental cleanliness, social justice, etc. In open civil societies of the western type the problem of social protection is reduced, on the one hand, to the provision of collective rights, on the other hand to ensure the rights of their representatives.

The Ukrainian society is characterized by a general social imbalance, a break in the internal-social relations, the tension between the population and the state, between the spiritual elite and the masses, and endless conflicts within the political elite. The outbreaks of conflict situations in Ukraine testify to the expansion of the social base of both ultra-right and ultra-left forces, the polarization of society against the backdrop of sharp stratification, first of all, property between the socially unprotected layers of the people and the authorities, which in a critical situation carries the threat of a public explosion and gives grounds for the activity of various political speculators.

People in a state of intrapersonal conflict are potentially dangerous for interpersonal relationships in the group, as the negative effects of the conflict are fraught with stress, neuroses, increased anxiety, general psychological depression of man or excessive aggressiveness, and can be directed to objects that do not have relation to the conflict. And if we keep in mind those who hold high positions in society, then they can have 
a negative impact on relations of a larger scale. Consequences of internal conflicts often lead to a decrease in labour productivity and even to accidents and man-made disasters. The ability to realize its internal needs and desires will reduce the number of conflict situations in society, which is an indicator of the viability of the system itself. [6, p. 48].

Such internal conflicts do not allow for the modern development of a democratic society in Ukraine with democratic values. Personal conflicts in the current social environment in Ukraine did not allow for reforms at the state and local levels. Officials were always in the election stresses that changed the key positions on 'their', which also came to power and realized that the cost of a position should be compensated and with the possibility of access to statepublic resources is an opportunity for rapid material enrichment. Under such conditions, a state-political conflict is very developed, which has prompted the development and prosperity of labour conflicts in public administration, and not the desire of civil servants to change something and frequency and to change themselves in the conditions of transnational development of world society.

Such conflicts have gone beyond the bounds of public administration and are increasingly gaining ground in public conflicts, as with the development of civil self-consciousness and civil society in Ukraine, with the rapid development of information resources, the issue of public and state administration becomes a widespread publicity.

From the development of information technologies and transnational transformations that take place around the world, people as individuals are even more advanced and require expression and internal growth, self-realization and recognition as a person.

Such events in the Ukrainian society deepen the inner personal conflict of the individual himself, the source of which is, nevertheless, the sphere of residence. Such researchers as both M. Bakunin and P. Sorokin argued about the necessity adaptation of the social environment to the needs of the individual, the implementation of the principle of human freedom and bringing human needs into line with the possibility of their satisfaction [7].

But not all individuals express their well-intentioned intentions, most often people want to influence the decisionmakers of states in order to profit their preferences and achieve material interests. Therefore, in this development of publicity, it is important as the country's largest policy to 'develop the spiritual values' and implement a system of democratic values.

A vivid example of a public conflict in Ukraine is the election of the President of Ukraine in 2019, which showed how the conflict becomes public, and this has already gone beyond the government of Ukraine and goes to the international level in the form of a public conflict as the struggle for power, state power and international influence. V. Zelenskyi provoked the acting President Poroshenko to enter a public debate. There was no such quick reaction to the public challenge of P. Poroshenko. Waiting for him a public reaction during the seizure of Ukrainian sailors, and it was not there. And here a serious impetus as the struggle for power was a challenge and went into a 
public conflict, an open confrontation and needed an appropriate reaction as to take part in the presidential election debates. So we will see one of the forms of conflict resolution as Presidential Debate. Thus, today we have a new form of conflict as public, which reflects the mood of society, the needs of the will-personality of the individual as the individual, the desire to make decisions in public administration, the sharp sense of justice and equality of rights and freedoms of the individual in social development.

We have no way back, the process of social change is no longer stopped, and the task of the Ukrainian political system is to translate it into a civilized way with an intelligent strategic prospect for Ukraine. In addition, European affiliation of Ukraine determines its development on the basis of civil society. It is the State which must first of all ensure the rights of its citizens and their social protection, and the new principles of its administrative and structural construction as to ensure the maximum reduction of corruption and clannishness.

A psychological basis for deterring a social explosion should be a certain level of tolerance as patience for representatives of different social groups. In the context of the prospects for the development of the state and society, tolerance should be considered not only as a potential for maintaining peace and tranquillity in the country, but also as an indicator of the readiness of the mass consciousness of the population for openness and cooperation on the principles of social justice. It accumulates human experience from generation to generation, about which K. Jung wrote in his writings.
Conclusions and prospects for further researches. Public conflict is inherently inherent and inexhaustible in its cognitive possibilities the object of attention from the side of society. Its roots lie in the dual nature of man, which develops no less rapidly, as the man himself, his social environment and mankind as a whole.

Modern as informational stage of human development expands the boundaries of human nature, whose noospheric dimension actualizes the archetypal potential of the collective unconscious in the solution of social conflicts.

Sigmund Freud and especially Carl Jung, who focused on the phenomenon of the collective unconscious as the centrepiece of the unity of the 'atomized' world of modern man, may well become the basis for reliable ideas, methodologies, and tools for resolving conflicts in the modern postmodern world.

\section{REFERENCES}

1. Piren, M I. (2003). Konfliktolohiia [Conflictology]. Kyiv: MAUP [in Ukrainian].

2. Vlasiuka O.S. (Eds.). (2002). Stratehii rozvytku Ukrainy: teoriia i praktyka [Strategy of Ukraine's Development: Theory and Practice]. Kyiv: NISD [in Ukrainian].

3. Odaynik V. (2010). Psikhologiya politiki: Politicheskie i sotsialnye idei Karla Gustava Yunga [Psychology of politics: Political and social ideas of Carl Gustav Jung]. Saint Petersburg: Izdatelskaya gruppa "Azbuka-klassika" [in Russian].

4. Shostrom E. (2008). Chelovek-manipulyator. Vnutrennee puteshestvie ot manipulyatsii k aktualizatsii [Manmanipulator. Internal travel from manipulation to actualization]. Moscow: 
Aprel-Press, Psikhoterapiya [in Russian].

5. Kuchma L. (2001). Ukraina na porozi XXI stolittia: uroky reform ta stratehiia rozvytku [Ukraine at the dawn of the $21^{\text {st }}$ century: lessons of reform and development strategy]. Materialy naukovoi konferentsii - Materials of the scientific conference. Kyiv: NTU KPI [in Ukrainian].

6. Khalin K. E., Klimova Yu. V., Levkina E. V., Bogatyreva N. A. (2009). Konfliktologiya [Conflictology]. Moscow: Ekzamen [in Russian].

7. Bakunin M. A. (2003). Izbrannye filosofskie sochineniya i pisma [Selected philosophical writings and letters]. Moscow: Mysl [in Russian].

8. Antsupov A. Ya., Shipilov A. I. (2007). Konfliktologiya [Conflictology]. ( $3^{\text {rd }}$ ed.). Saint Petersburg:Piter [in Russian].

9. Vashchenko I. V. (2001). Obshchaya konfliktologiya [General conflictology]. Kharkov. Retrieved from http:// www.economics.com.ua/writer/3996/ textbook/11560/tyurina_va/ konfliktyi_i_upravlencheskaya_deyatelnost/read [in Russian].

10. Dmytrenko M. (2011). Politychna systema Ukrainy: rozvytok $\mathrm{v}$ umovakh hlobalizatsii i informatsiinoi revoliutsii [Political System of Ukraine: Development in the Conditions of Globalization and Information Revolution]. Kyiv: Universytet "Ukraina" [in Ukrainian].

11. Dmytrenko M. A. (2010). Innovatsiini stratehii rozvytku Ukrainy: politolohichnyi kontsept [Innovative Strategies for the Development of Ukraine: Political Science Concept]. Kyiv: Universytet "Ukrainy" [in Ukrainian].

12. Sytnyk H. P. (2009). Zakhyst natsionalnykh interesiv - priorytet profi [Protection of national interests - pros' priority]. Nar. armiia - People's army, 51, 5 [in Ukrainian].
13. Halchynskyi A. S., Vlasiuk O. S., Varnalii Z. S. et. al. (Eds.). (2004). Ukraina: stratehichni priorytety. Analitychni otsinky - 2004 [Ukraine: Strategic Priorities. Analytical assessments 2004]. Kyiv: NISD [in Ukrainian].

\section{СПИСОК ВИКОРИСТАНИХ ДЖЕРЕЛ}

1. Пірен М. І. Конфліктологія: підручник. - К.: МАУП, 2003. - 360 с.

2. Стратегії розвитку України: теорія і практика / за ред. О. С. Власюка. К. : НІСД, 2002. - 864 с.

3. Одайник B. Психология политики: Политические и социальные идеи Карла Густава Юнга / В. Одайник. СПб.: Издат. группа "Азбука-классика”, 2010. - 256 с.

4. Шостром Э. Человек-манипулятор. Внутреннее путешествие от манипуляции к актуализации. М.: Апрель-Пресс, Психотерапия, 2008. - 192 с.

5. Кучма Л. Україна на порозі ХХI століття: уроки реформ та стратегія розвитку // Матеріали наукової конф. - К.: НТУ КПІ, 2001. - С. 11.

6. Халин К. Е., Климова Ю. В., Левкина E. В., Богатырева Н. А. Конфликтология. - М.: Экзамен, 2009. - 237 с.

7. Бакунин М. А. Избранные философские сочинения и письма. - М.: Мысль, 2003. - 573 с.

8. Анцупов А. Я., Шипилов А. И. Конфликтология: учеб. для ВУЗов. 3-е изд. - СПб.: Питер, 2007. $496 \mathrm{c.}$

9. Ващенко И. В. Общая конфликтология. - Харьков, 2001. http:// www.economics.com.ua/writer/3996/ textbook/11560/tyurina_va/ konfliktyi_i_upravlencheskaya_ deyatelnost/read 6

10. Дмитренко М. Політична система України: розвиток в умовах гло- 
балізації i інформаційної революції: монографія / М. А. Дмитренко. - К.: УН-т “Україна”, 2011. $820 \mathrm{c}$.

11. Дмитренко М. Інноваційні стратегії розвитку України: політологічний концепт: монографія / М. А. Дмитренко. - К.: УН-т "Україна”, 2010. -504 c.
12. Ситник Г. П. Захист національних інтересів - пріоритет профі / Г. П. Ситник // Нар. армія. 2009. - № 51. - C. 5.

13. Україна: стратегічні пріоритети. Аналітичні оцінки - 2004 / Ред. кол.: А. С. Гальчинський, О. С. Власюк, 3. С. Варналій та ін. - К.: НІСД, 2004. - 169 c. 